\title{
Child's Right to Education Under South Africa Law in Human Right Perspective
}

\author{
Momodu Wisdom \\ Embassy of the Federal Republic of Nigerian, Berlin, Germany \\ Onyenajua Coleman Thompson \\ University of Port Harcourt, Rivers State, Nigeria
}

\begin{abstract}
For several decades, education has played a vital role in shaping human existence. Several commentators have commented on education and its advantages to man and institutions but it has not solve the problem sourounding the rights of a child to quality education. The right to have life is closely linked to right to education, as the importance of education cannot be ignored by any institution. Education is the bedrock of any society. The lack of it is synanimous to lack of right to life itself. Education is a necessary without which no one can reasonable exist. For children to unlock their potentials, the right to education must be enforced or implemented by all nations of the world.

This article explains the right of a child to education and its link to other social and economic rights. It goes further to give a general overview on the features of education, which include but not limited to availability, accessibility, acceptability, and adaptability.
\end{abstract}

Keywords: human rights, child's rights, social justice

\section{Introduction}

\section{Education}

Education is the bedrock of any society whether developing or industrial society. The importance of education to the growth of a nation cannot be over emphasis and this is based on the premise that the growth of any nation's economy and its strength lies on proper and equipped education where full potentials are realised.

The most essential element for the upbringing of a child and development in order to actualised his full potentials and secure their rightful place in the society lies on educational right. ${ }^{1}$ The right to education is bestowed with dignity that allows access to nation's wealth. This is the reason why education is as important as the support of the body, society, and the world at large, without which the cross pollination of ideas that keeps the world going would have not be possible.

Education is a master key that unlocks other rights that are provided for by the Constitution ${ }^{2}$ as it relates to employment, good and better income, housing, good health care, and other economic benefits. ${ }^{3}$ Education as

Momodu Wisdom, Ph.D., LL.B, LL.M, Embassy of the Federal Republic of Nigerian.

Onyenajua Coleman Thompson, LL.B, LL.M, Department of Public Law, Faculty of Law, University of Port Harcourt.

1 Boezaart, "Child Law in South Africa" 399.

2 Sec. 27 of the Constitution of Republic of South Africa 1996.

3 Boezaart, ibid. 
human rights is a means of achieving other human rights. ${ }^{4}$ It is the medium by which marginalised children and adults bring themselves out of poverty. When education is not in place, poverty remains a perpetual property of anyone who is been denied of these rights. It is regarded as an empowerment right that has a vital value of empowering women to safeguard the destiny or future of the children and the society at large; protecting children from all forms of exploitation and worst form of labour; promoting human rights, democracy, and dignity; protecting and enhancing the society economically and controlling population growth. ${ }^{5}$

Under Sec. 29 of the Constitution of the Republic of South Africa (hereafter the Constitution), it provides for the right of education ${ }^{6}$ in both public and private levels, but that of the private must be in line with the standard of the public school. ${ }^{7}$ This is to bring competition in learning and development of human ideas and potential for economic growth. The significance of the provisions of subsection 3 of the Constitution is to grant freedom of choice between public and private schools by recognising the right to establish and establish independent educational institutions.

Under international law, the right to education enjoys protection as well. The Universal Declaration of Human Rights ${ }^{8}$ was the first international instrument to recognise and give expression to the right to education. It states that:

Everyone has the right to education which shall be free at least in the elementary and fundamental stages... elementary education shall be compulsory. ${ }^{9}$

The right to education was felt by the world as a basis of better life for children and the society in general. The future of the world lies on the children and if the future is not protected by giving them the right to education in order to bring out their full potentials which invariably is the benefit of the entire society, the future of the world will also not be secured. The strength of a nation is based on the capacity of its human resources and education plays a vital role here and without it a nation's growth is stunted.

Under Art (Article) 29 of the Convention on the Rights of a child (hereafter the CRC), the right to education was also provided for where state parties are in consensus adidem that the education of the child should be directed to the development of the child's personality, talent, and mental and physical abilities to their fullest potentials. ${ }^{10}$ Under Art 32 of the CRC, the right of child's education was given full meaning where state parties are to protect the child from exploitation and all form of child labour that will hinder the child from going to school. The right to education enjoys a high protection under international law and this is based on the benefit which derives from education both as an individual, nation, and the world in general. There are several other international and regional instruments that guarantee the child's right to education. This includes Art 4 of the United Nations (UN) Educational, Scientific and Cultural Organisation 1960, International Covenant on Social, Economic and Cultural Rights 1976, Art 11 of the African Charter on the Rights and Welfare of the Child 1999, Art 17 of African Charter on Human, and Peoples Rights 1986 just to mention but a few.

\footnotetext{
${ }_{5}^{4}$ UN Economic and Social Council The Right to Education 1.

${ }^{5}$ UN Economic and Social Council The Right to Education 1.

${ }^{6}$ Sec. 29 of the Constitution of Republic of South Africa 1996.

${ }^{7}$ Sect. 29(3) of the Constitution of Republic of South Africa 1996.

${ }^{8}$ Universal Declaration of Human Rights 1948.

9 Art 26 of The Universal Declaration of Human Rights 1948.

${ }^{10}$ Art 29(1)(a) Convention on the Rights of the Child 1989.
} 
In the case of Section 27 and 2 Others v Minister of Education and Another, ${ }^{11}$ Kollapen J stated that:

Most society, ours included, place a high premium on education. Not only is it a means by which individuals are able to fulfil their potential, it also provides in a wilder sense the basis for development and uplifting. Accordingly in the context of International Human Rights Law and increasingly in context of National legal system. ${ }^{12}$

Education according to Kollapen $\mathrm{J}$ in the instant case is not only the benefit of an individual but to the development and uplift of the society who are placed under obligation both nationally and internationally to ensure education is at the reach of every one especially making free and compulsory education at the basic level for children who are seen as the nucleus of the society.

Sec. 29 of the Constitution ${ }^{13}$ provides for the right of education and this is to bring equality within the diverse society that is prevailing in South Africa (SA). And it states as follows:

(1) Everyone has the right to-

to basic education, including adult basic education; and

to further education, which the state, through reasonable measures, must make progressively available and accessible.

(2) Everyone has the right to receive education in the official language of their choice in public educational institutions where that education is reasonably practicable. In order to ensure the effective access to, implementation of, this right, the state must consider all reasonable educational alternatives, including single medium institutions, taking into account-

equity;

practicability; and

the need to redress the result of past racial discriminatory law and practices.

The Constitution provides for right to education at all levels but with different measures of attaining the realisation of the said obligations. At the basic level, the state is under the obligation to immediately realise the obligation of given good and quality education to children. The state is under negative obligation as provided by Sec. 7 of the Constitution to respect ${ }^{14}$ the rights as contain in the Bill of Rights. In Centre for Child Law $v$ Minister of Basic Education, ${ }^{15}$ the state was ordered to provide the children who were in alternative care in the hostels sleeping bags and psychological services. It was further held that it is not a right that needs progressive measure to be realised and that it was an immediate right which the state was under obligation to protect.

Further education is limited by the limitation clause, ${ }^{16}$ as it has to do with the state resources which have to be achieved through reasonable measure with available resources. In discharging this obligation, the state is judge on the basis of reasonableness. The state must proof this—reasonable measure with available resourcesby explaining the measure put in place to realise this obligation on the ground of comprehensive, coherent and coordinate, balance and flexibility, awareness, non-discriminating unfairly, taking the most vulnerable into consideration and to adopt transparency in its actions as a progressive measure adopted.

The best interest of the child as provided for by the Constitution also plays a vital role on the right to education. This is on the premise that in determining the state of a child in the society education especially basic education lays the foundation of success to all other access to quality life and education is the best interest

${ }_{11}$ Section 27 and 2 Others v Minister of Education and Another 24565/2012[2012] ZAGPPHC 114.

${ }_{12}$ Sec. 27 and 2 Others v Minister of Education and Another 2012 case No 24565/2012 at 20 (1)

13 Sec. 29(1) and (2) Constitution of the Republic of South Africa 1996.

${ }_{14}$ Sec. 7(2) Constitution of the Republic of South Africa 1996.

1520124 All SA 35 (ECG).

16 29(1)(b) Constitution of the Republic of South Africa 1996. 
that should be paramount ${ }^{17}$ to the child. In Governing Body of the Juma Musjid Primary School and 2 Others $v$ Ahmed Asruff Essay NO and Others, ${ }^{18}$ Nkabinde J observed that the High Court failed to give efficacy to the guaranteed rights contained in Sec. 29(1) and 28(8) of the Constitution. He referred to the case of Director of Public Prosecutions, Transvaal v Minister for Justice and Constitutional Development and Others ${ }^{19}$ and held that the provisions of Sec. 28(2) of the Constitution imposes an obligation on all who are entitled to make decision concerning a child and to ensure that the best interest principle is dully considered.

The right to education is not only a human right but a right to access other human rights which culminates into the realisation of individual full talents or potential that secures one's social security.

In giving effect to quality and equal right to education in South Africa, the South African School Bill was drafted and published by the Government Gazette for public comment ${ }^{20}$ and it became law in 1996, as South African Schools Act 84 of 1996 (hereafter the Act) and was implemented in 1997. Under Sec. 3(1), the $\mathrm{Act}^{21}$ imposed a compulsory obligation on the parents to see that the learner attends school whether public or independent school starting from the first day of the year when such a learner is seven years old to the last day of the year when such a learner reaches the age of 15 years old or the ninth grade whichever occurs first. $^{22}$

The learner, as used, refers to the child who the parent must ensure the responsibility of going to school. This does not necessarily put all the responsibility on the parent financially but the parent is to see that the fundamental right to education, especially the right to basic education as provided for by the Constitution, is secured.

All the Members of Executive Council in a particular province are equally mandated by the $\mathrm{Act}^{23}$ who are responsible for education matter in their respective province to make sure there are enough schools which will be convenient for the child in that province to attend and when such responsibility cannot be complied with due to lack of capacity, he or she must take step to remedy the lack of capacity. ${ }^{24}$

The responsibility to ensure the basic fundamental right to education of the child is placed on both government and the parents. The question that readily comes to mind is what happened when the parents are indigent? This question will lead us to education as a link to other human rights.

\section{Education as a Link to Other Social Rights}

Education is the key that unlocks the other human rights available to humans and without it all other rights is difficult to access. It is an empowerment right which is seen as the primary vehicle by which adults and children that are economically and socially marginalized can lift up themselves out of poverty and empower themselves with the means to be active in the society. ${ }^{25}$ Education is not a means in itself but a means to an end. Sec. 27 states:

Everyone has the right to have access to-

Health care services, including reproductive health care;

Sufficient food and security; and

\footnotetext{
17 Sec. 28(2) Constitution of the Republic of South Africa 1996.

182011 ZACC 13.

192009 (4) SA 222 (CC).

${ }^{20}$ GN 196 in GG 1631215 March 1995.

21 Sec. 3(1) The South African Schools Act 84 of 1996.

22 Sec. 3(2) The South African Scools Act 84 of 1996.

23 Sec. 3 South African Schools Act 84 of 1996.

24 Governing Body of The Juma Musjid Primary School and 2 Others v Ahmed Asruff Essay N O and Others 2011 ZACC 13.

${ }^{25}$ UN Economic and Social Council The Right to Education 1-2.
} 
Social security, including, if they are unable to support themselves and their dependents, appropriate social assistance. $^{26}$

One has to be empowered financially to have access to health care, food, and housing, and education gives such power because it is one of the powerful key to employment. It is one of the crucial roles in the fulfilment of socio economic rights.

The international law which can be referred to as provided for under Sec. 39 of the Constitution ${ }^{27}$ if applicable gave basic education a priority above other levels of education by obligating states parties to make it compulsory and free. ${ }^{28}$ This is on the premise that it is the access to the enjoyment of other human rights and also empowers one to play an active role in the society. For example, an educated person is capable of making a choice at the political arena, like choosing a candidate to represent him in any political office or standing as a candidate to run for a political office. Kollapen $\mathrm{J}$ held in Section 27 case $^{29}$ that the right to education is not a standalone right but it is a means by which other rights are realised. The South African Government in her General Notice 196 on White Paper on Education and Training stated that:

Education is the cornerstone of any modern, democratic society that aims to give all citizens a fair start in life and equal opportunities as adults. ${ }^{30}$

Though basic education is made free and compulsory for children from age 7 to 15 or until he or she reaches the 9th grade, there are other financial burdens that are associated with education, for example transport fair, feeding, and school uniform. These are some of the challenges that are faced by indigent parents to comply with. But with the help of social assistant, ${ }^{31}$ this can be realised as the state alleviate this burden by creating various grants to enable basic education realisable. State grant as in form of social assistant can go a long way assisting the indigents in realising the educational right where the talents or potentials of the individual can be fully realised in order to be active in the society.

For one to assert a right, for example, social economic rights, he has to know of the existences of these rights and education, specifically basic education, plays a vital role here. Under Sec. 7(1) of the Constitution, ${ }^{32}$ the state is under obligation to respect, protect, promote, and fulfil the rights contained in the Bill of Rights. In fulfilling this right, it is to create awareness of the existence of the available rights and this can be done through the process of learning in schools. Only a literate person can know how to go about enforcing the right that is breached, a lot of cases are lost not because it was not a good one because the technical knowhow was poor and the information provided was not accurate enough due to lack of knowledge. This is one of the reason why education is important in realising other rights, be it social economic rights or civil and political rights.

The right to access to housing still bore down to employment which has a link to education. The right of children to shelter in Grootboom case $e^{33}$, which was not taking as paramount interest by the Constitutional Court

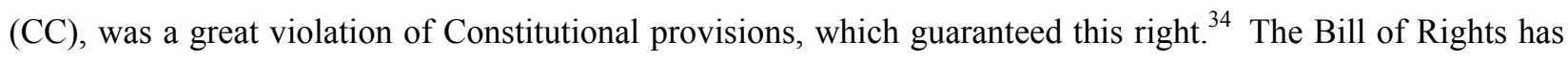

\footnotetext{
26 Sec. 27 Constitution of the Republic of South Africa 1996.

27 Constitution of the Republic of South Africa 1996.

28 Arendese, "Obligation to Provide Free and Basic Education in South Africa" 101.

29 Case No 24565/2012.

GN 196 in GG 16312 of 15 March 1995.

31 Sec. 27(1)(c) Constitution of South Africa 1996.

32 Constitution of the Republic of South Africa 1996.

332001 (1) SA 46.

34 Sec. 28(1)(C) Constitution of the Republic of South Africa 1996.
} 
pointed it out that in every matter concerning a child, the best interest of the child should be of paramount consideration $^{35}$ and in Grootboom case, the children shelter was not put into consideration in setting aside the decision of the High Court and if the children has no shelter, how can they go to school and how can the parents exercise their parental duties as placed upon them under the South African Schools Act ${ }^{36}$ to ensure children or learner attends school? The court also failed to consider the effect of harsh weather on the children by taking blind eyes on the fact that children can be vulnerable to disease which will affect their health. And the reasons in the case of Soobramoney ${ }^{37}$ where it was stated that it will be better to save life than to prolong life; this rule might be followed should the children fall sick.

Furthermore, Social Assistance encompasses housing or shelter as the case maybe which is right guaranteed by the Bill of Rights and the state is obliged to respect, protect, promote, and fulfil ${ }^{38}$ this right and the state is obliged to honour the obligation placed on her by the Constitution. The state always uses the limitation clause of available resources, progressive measures, reasonable and legislative measures when dealing with social economic rights. The question is: Was it reasonable for Groothboom and her children to be placed in a waterlogged area as a temporary place pending when their permanent residence will be made available? The answer is simply "no" because it is unreasonable to place human beings in such an environment thereby robbing them of their dignity which the court again failed to consider. Vulnerability is one of the conditions the court looks at in judging the reasonableness of state action and this is lacking in the judgement thereby placing the children homeless. One of the significances of Grootboom case decision is that the ministry responsible for allocating houses to needy citizen will slow down their actions as court has given a loophole to hide and the destiny or potentials of children are put on the line.

Though the state cannot do more than the available resource but they ought to be reasonable in their administrative actions as it relates to socio economic rights.

\section{Features of Education}

Education has a lot of features as a going concern but the most essential features are availability, accessibility, acceptability, and adaptability. ${ }^{39}$ These are the most fundamental features which all forms of education must exhibit in order to function properly.

\section{Availability}

For education to function as an institution, the available school programmes has to be available in a sufficient quantity within the state party jurisdiction. Under the provisions of Sec. 3 of the $\mathrm{Act}^{40}$, it places the duty on the Member of Executive council of a province to provide places for schools so that every child who lives around such province can attend school. This is a form of delegated duty from the state to the Member of Executive Council as one of its organ. In the case of Governing Body of the Juma Musjid Primary School and Others $v$ Ahmed Asruff Essay N O and Others ${ }^{41}$ (hereafter Juma's case), the Constitutional Court referred to Sec. 12(1) and (2) of the Act which states that:

\footnotetext{
35 Sec. 28(2) Constitution of the Republic of South Africa 1996.

36 Sec. 3(1) South African Schools Act 84 of 1996.

371998 (1) SA 765 (CC).

${ }^{38}$ Sec. 7(2) Constitution of the Republic of South Africa 1996.

${ }^{39}$ UN Economic and social Council The right to Education 2-3.

40 South African Schools Act 84 of 1996.

412011 ZACC 13.
} 
The Member of Executive Council Must provide public Schools for the education of Learner out of fund appropriated for this purpose by the provincial legislation

The provision of public school referred to in subsection (1) may include the provision of hostels for the residential accommodation of the learner. ${ }^{42}$

From the wording of the provision in subsection 1 of Sec. 12 of the Act, the word "must" is used, which means they are under direct obligation to provide public schools for the education of learner. They failed to do in the present case and they subjected the school authority to litigation as they have failed to pay the rent of the property which was a great violation of the Bill of Rights by subjecting the students to psychological trauma. Section 7 of the Bill of Rights specifically provide for the rights contained in the Constitution to be respected, protected, promoted, and fulfil, these where lacking according to their conduct until an eviction order was obtained from the High Court which was set aside based on the fact that the best interest of the child was not taking as paramount ${ }^{43}$ but the Constitutional Court again gave another order for them to vacate the premises as their duty is to provide a learnable place for the education of the learner and not the trustees.

School requires some vital factors to function and much more the developmental context of operation. ${ }^{44}$ Building is a vital factor which must be made available for all institutions and this was the subject matter in Juma's case. While most institution will require facilities like sanitation for boys and girls, good drinking water, skilled teachers, teaching materials which must be made available on time, good and comfortable desks, recreation facilities, and the likes; some will require sophisticated facilities like library, computer, and the likes. These depend on the operation mechanism within which institution operates. In Sec. 27 and 2 Others v Minister of Education and Others, where school materials were not delivered to the schools in Limpopo province was held to be a great violation of the right to basic education and the court ordered that school material and a follow-up plan should be given to the students and report should be sent to the court on monthly basis on the measure adopted to ensure the students catches up with academic work.

In Juma's case, it was held that right to basic education is an unqualified right which should be immediately realisable but how can this right be realised when schools like in the case of Section 27 have no school materials? This is highly unreasonable and Kollapen $\mathrm{J}$ in his judgement stated that:

Accordingly, I conclude the failure by the Respondents to provide text books, constitutes a violation of the right to basic education. In this regard I wish to point out that I do not characterise the respondent's conduct as being mala fide. On the contrary they may have acted in good faith, but that is hardly decisive for the reasons I have already given. The fact of the matter is that the measure they took was not reasonable; having regard to the urgency of the situation and having regard to their own targets and indicators they had set in respect of the delivery of textbooks.... 45

In order to realise the intent and purpose of the provision of Sec. 29 of the Constitution, ${ }^{46}$ schools are supposed to have available or sufficient staff both academic staffs and non-academic staffs for the smooth running of the school and to ensure duties are not overlapping. In Centre for Child Law v Minister of Education and Others, ${ }^{47}$ where there was lack of non-academic staffs and academic staffs, the ministry of Basic Education and all the joined parties were ordered to provide and confirmed the position of the staff concerned

42 South African Schools Act 84 of 1996.

${ }^{43}$ Sec 28(2) Constitution of the Republic of South Africa 1996.

${ }^{44}$ UN Economic and Social Council The Right to Education 2.

45 Section 27 and 2 Others v Minister of Education and Another 2012 case No. 24565/2012.

46 Constitution of the Republic of South Africa 1996.

47 Case No 1749/2012. 
as this was a violation of basic education rights and the right to basic education is to be promoted, respected, protected, and fulfilled as provided for under Sec. 7(2) of the Constitution. The Ministry of Education is empowered to and obliged to determine the establishment for both non-academic staff and academic staff in public primary school in the province. The quality of education is impaired without the required staffs in school and the learning process naturally slows down if not killing the system and the potentials which the Bill of Rights purport to achieve for better human existence is breached and the dignity of the children is put on the line and thereby rendering impotent the intent and purpose of both international and regional instruments which support basic education to be free and which the court declared in Juma's case to be unqualified right if not made available for a better and quality education.

According to Boezaart, ${ }^{48}$ he asserted that availability connotes the availability of educational opportunities and facilities, such as schoolteachers and learning materials, but also to the condition and competency of the available facilities and teachers. The available educational opportunities could be seen from the perspective of the ability to access the opportunity to learn by having all the vital requirement needed to learn which includes teaching and non-teaching staffs, learning materials, and the likes and these most be based on good condition of competency. The salaries of the teachers and non-teaching staffs have to been paid in order to engage them in quality service for the benefit of the children whose interest holds paramount in this regard. To this end, availability as one of the essential features of education is the first step to take as a reasonable measure in fulfilling the socio economic rights of children in educational sector.

\section{Accessibility}

The primary aim of the socio and economic rights as it relates to education is to restore human dignity. Everyone should have access to education without discrimination in all ramifications. In General Comment (GC) 13, accesses to education are divided into three spheres, which are non-discrimination, physical accessibility, and economic accessibility. ${ }^{49}$

\section{Non-discrimination}

Educational access must not be discriminated against at all as this right is guaranteed under the Constitution. Under Sec. 7(2) of the Constitution, ${ }^{50}$ it provides that all the rights contained in the Bill of Rights must be respected, protected, promoted, and fulfilled. And under Sec 9(3) and (4), the Constitution also stipulates that no one should be discriminated against whether directly or indirectly in any form as it relates to race, gender, sex, pregnancy, marital status, ethnic or social origin colour, sex, religion, and the likes. The court has reiterated the fact that in exercising the principle of reasonableness, the most vulnerable groups should be given priority ${ }^{51}$ and education should be as accessed by all, especially the most vulnerable. In Prinsloo $v$ Van der Linde, ${ }^{52}$ the court posited that unfair discrimination as prohibited by Sec. 9(3) of the Constitution should be determined against the background of the previous era of unequal treatment of people where their inherent dignity was denied. The issue of language barrier should not be an obstacle to educational accessibility.

\footnotetext{
48 Boezaart, "Child Law in South Africa" 402.

${ }^{49}$ UN Economic and Social Council The Right to Education 3

${ }^{50}$ Constitution of the Republic of South Africa 1996.

51 Minister of Health and Others v Transmission Action Campaign and Others 20025 SA 721 (CC).

5219974 SA 1 (CC).
} 
Under the National Educational Policy Act, it commits the education authorities to promote multilingual and also develop official language out of all the languages used in South Africa. ${ }^{53}$ Furthermore, Sec. 7(2) gives effect to Sec. 15(2) of the Constitution as all the rights in the Bill of Rights should be respected and religion is not an exception. As contained in the preamble of the Constitution, it is quite obvious that South Africa is diversified and the Constitution asserts the unification of all in South Africa in respective of the diversification of the Country and the right against discrimination at all spheres of life in South Africa, as this will bring the achievement of unity and it starts with education which is the bedrock of every nation. Non-discrimination as an access to education should be based in law and in fact.

\section{Physical Accessibility}

In terms of Sec. 3 of the Act, ${ }^{54}$ it provides that every Member of the Executive Council of a province is bestowed with educational responsibilities and they are mandated to ensure that there are sufficient schools in place, so that children in that province can easily access to school. In this respect, education has to be within the physical reach of the children either by attendance at a reason and convenient distance or through modern technology. ${ }^{55}$

The child should be able to enrol without difficulties and attend school. In the case of Adam Legoale and Others $v$ The MEC of the Department of Education North West and Others ${ }^{56}$ (hereafter the Siga Village case), the school was placed far from the village and it was difficult for the children to go to school, and as a result, some children stopped going to school, which was held by the court that it was a violation on the right of the children to education as the children's access to school is impaired. Consequently, the court ordered the defendant to make transport arrangement for the children to go to school and the parents to claim compensation for what they have incurred as result of lack of access to school.

\section{Economy Accessibility}

In realising the right of education, it should be made affordable. The basic education should be free. ${ }^{57}$ Though the Constitution has made it clear that child has right to basic education and the state is to make use of its available resources to progressively realise the further education. ${ }^{58} \mathrm{Sec} .7(2)$ gives effects to the provisions of Sec. 29 as state is to respect, protect, promote, and fulfil this right. Also the social assistant ${ }^{59}$ grant is also a way whereby the state supports children through school and to make education more economically accessible.

More children are still out there not going to school even with the sanction imposed on this regard, which requires a parent who fails in this obligation to send their children to school to six months in prison. This sounds like a balance and check method but some of this grant are not always enough to take full responsibility of this kind, especially the indigent parents. The government should do more by increasing the social grant of children and to totally make school free by removing fees, such as uniform fee and examination fee, and to provide transport system to ease the system.

\footnotetext{
53 Boezaart, ibid 481.

54 South African Schools Act 84 of 1996.

${ }^{55}$ UN (United Nations) Economic and Social Council The Right to Education 3.

${ }^{56}$ Case No 499/11.

57 Art 13 International Covenant on Social Economic and Cultural Rights.

58 Sec. 29 Constitution of Republic of South Africa 1996.

59 Sec. 27(1)(C) Constitution of Republic of South Africa 1996.
} 


\section{Acceptability}

The curricular and teaching methods of a school have to be acceptable both nationally and internationally to students. The form and substance of education should not go down below the minimum standard as may be approved by the state. ${ }^{60}$ In Centre for Child Law and Others $v$ The Minister of Basic Education and Other ${ }^{61}$ it was held that the lack of both academic and non-academic staffs was not an acceptable form of education and the non-payment of teachers' salaries was not an acceptable form of education and the learning process by the students is obstructed by not motivating the workers by paying them salaries and also lacking staffs.

Furthermore, in the case of Section 27 and 2 Others $v$ Minister of Education and Another, ${ }^{62}$ it was held that the no-supply of school materials to students was a violation to educational rights of the children. The form and standard were unacceptable as the students lack materials for learning to equally prepare for their examinations. The question that readily comes to mind in this case is: What kind of judgement could be just and equitable in this regard? The school ranked low in their performance across the nation of South Africa, how can they remedy this situation as regards to time that was been wasted? The Bill of Rights posited that everyone is equal, ${ }^{63}$ certainly equality has not come to play in the instant case, base on the premise that while some are going to the next level of academic class, some will be repeating their academic class which was the negligence of the state and the form or standard of education is unacceptable in this regard as this constitutes one of the nucleus of education.

For education to be acceptable does not necessarily refers to and include the curricular plan, the teaching methods, and the quality of teachers in an institution only, it also includes sanitation as regard to good toilet, good water system, and relaxation places during break or recess. This will help to safeguard the student health to the least minimum of contacting diseases from the toilets, especially the female students.

\section{Adaptability}

Due to the changing circumstances around the globe, the teaching and the learning process should not be static, in other words, the education curriculum and the teaching pattern have to be flexible in order to entertain new ideas to bring education into discovery of ideas on a continue basis. During the 70 century, the use of computer in school was not known but later schools started to recognise this form of learning and teaching by using computers in school and the introduction of these tools of learning has done a lot of good to educational sector around the globe. Boezaart ${ }^{64}$ asserted that adaptability is the process of accommodating children with special needs. But in this present dispensation, this assertion is too remote in the sense that the concept of adaptability as regards children basic right to education is broad enough to include all children in assimilating new ideas brought into the school system in realising their potentials in becoming active players in the society.

Adaptability is the student inclination to be able to solve difficulties under academic system and to be able to relatively obtain good academic performance. This pertains to study behaviour or study skills that will enable the student to obtain good academic grades. ${ }^{65}$

\footnotetext{
${ }^{60}$ Sec. 29(3)(C) Constitution of the Republic of South Africa 1996.

${ }^{61}$ Case No 1749/2012.

${ }^{62}$ Case No 24565/2012.

63 Sec. 9 Constitution of Republic of South Africa 1996.

64 Boezaart, ibid 402.

${ }^{65}$ DU (2008). "Education and Society” (pp. 21-35).
} 
An educational system must be able to cultivate intellectual versatility on its students in order to have a broader view or adapt to new areas of development in academic work. ${ }^{66}$ The environment for learning has to be conducive for students and should be good and safe for learning and also the language should be simple enough for the students to encode.

\section{Conclusion}

Education is directed to the full realisation of children potential, to this end, the provisions of education rights by the Constitution is direct and comprehensive. If history is to be traced, the provisions of the Constitution in safeguarding the economic and social rights, it would be agreed that the state is doing their best in realising these rights progressively and this is based on the premise that educational rights are at the reach of everybody, in the sense that both white and black children have equal access to education and their rights are recognised, as the breach of any of these rights can be addressed in court. This juxtaposes the situation now and the situation during the era of apartheid, despite the fact that there are some lapses and the government cannot go outside their available resources.

Traditionally, legal provision wants immediate realisation of the rights provided for by the Constitution but naturally it is not possible to immediately realise these rights due to the resources available to the state. However, this does not give the state the credit or lean way to hide under such circumstance where there are enough resources to realise the rights as guaranteed by the Constitution and again, when laws are necessary in realising these rights, enactment and implementation of such laws are said to be of immediate realisation. The state is to be reasonable, coherent or coordinate, flexible, create awareness, and be transparent in discharging their responsibilities towards the citizen especially children who are the most vulnerable in all circumstances by putting their interest in paramount consideration in every matter concerning them.

The $4 \mathrm{~A}^{\prime} \mathrm{s}^{67}$ as it relates to educational right should be maintained in given basic education to children because each links the other and the breach of one is the breach of others; the state has to take all necessary actions to ensure quality basic education is given to children in the realisation of their full potentials in order to be active in the society. The right to basic education is a master key that opens all other doors relating to social economic rights and the effect of social assistance compliments economic accessibility to education that the state must respect, promote, protect, and fulfil, as stated under Section 7(2) of the Constitution.

\section{References}

\section{Literatures}

Arendese, L. (2011). Obligation to provide free and basic education in South Africa: An international law perspective. PER/Potchefstroom Elec. L.J., 14(6), 97-112.

Boezaart, T. (2009). Child law in South Africa (Juta Pretoria 2009). Juta and Company (PTY) Ltd.

DU, P. (2014). Factors influencing students adaptability in school: A production model and multilevel analysis. Chinese Education and Society, 41(5), 21-35.

Majid, A. (2012). Globalization and education: A philosophical perspective on intellectual adaptability. Euromentor, 3(3), 7-21.

\footnotetext{
${ }^{66}$ Majid (2012). Euromentor (pp. 7-21).

${ }^{67}$ Availability, Adaptability, Accessability and Acceptablity.
} 


\section{Case Law}

\section{Appendix}

Adam Lagoale and Others V MEC of the Department of Education North West and Others Case No 499/2011

Centre for Child Law v Minister of Basic Education 20124 All SA 35 (ECG)

Centre for Child Law v Minister of Education Case No 1749/2012

Director of Public Prosecutions, Transvaal v Minister for Justice and Constitutional Development and Others 2009 (4) SA 222 (CC)

Governing Body of Juma Musjid Primary School and 2 Others v Ahmed Aruff Essay N O and Others 2011 ZACC 13, Nkabinde J observed that the High Court failed to give efficacy to the guaranteed rights contained in Sec. 29(1) and 28(8) of the Constitution.

Government of the Republic of South Africa and Others v Grootboom 1996 (4) SA 744 (CC)

Minister of Health v Transmission Action Campaign and Others 20025 SA 721 (CC)

Prinsloo v Van der Linde 19974 SA 1 (CC)

Section 27 and 2 Others v Minister of Education and Another Case No 24565/2012, Kollapen J stated that: Most society, ours included, place a high premium on education. Not only is it a means by which individuals are able to fulfil their potential, it also provides in a wilder sense the basis for development and uplifting. Accordingly in the context of International Human Rights Law and increasingly in context of National legal system.

Soobramoney v Minister of Health (kwaZulu-Nata) 1998 (1) SA 765 (CC)

\section{Legislation}

Sec. 7, 9, 26, 27, 28, Constitution of the Republic of South Africa

Constitution of the Republic of South Africa 1996

Sec. 3, 20 South Africa Schools Act

South Africa Schools Act 84 of 1996

International Instruments

Art 13 International Covenant on Social Economic and Cultural Rights International Covenant on Social Economic and Cultural Rights 1966 Art 29 Convention on the Rights of the Child (CRC)

Convention on the Rights of the Child 1989

GN 196 in GG 1631215 March 1995

United Nations Economic and Social Council The Right to Education (Art 13) E/C. 12/1999/10

Universal Declaration of Human Rights 1948 